DOI:

УДК 346.21

\title{
Наталія Ментух,
}

кандидат юридичних наук, доиент, дочент кафедри конституиійного, адміністративного та фінансового права Тернопільського начіонального економічного університету

ORCID: http://orcid.org/0000-0003-1078-9191

\section{ПРАВОВЕ СТАНОВИЩЕ ОРГАНІВ УПРАВЛІННЯ ЛІЗИНГОВОЇ КОМПАНІЇ У ФОРМІ АКЦІОНЕРНОГО ТОВАРИСТВА}

Розглянуто питання управління діяльності лізингової компанії як основного учасника лізингової діяльності, без якого неможливе нормальне функціонування лізингового процесу, який може задовольнити потреби в лізингових послугах на професійній основі, та до якого в науці господарського права зріс науковий інтерес. Розроблені та сформульовані основні теоретичні і практичні положення щуодо органів управління лізинговою компанією у формі акиіонерного товариства.

Ключові слова: лізингова компанія, органи управління, акціонерне товариство.

\section{Meнmyх $\mathrm{H}$.}

Правовое положение органов управления лизинговой компании в форме акционерного общества

Рассматривается вопрос управления деятельностю лизинговой компании как основного участника лизинговой деятельности без которого навозможно нормальное функиионирование лизингового процесса, который сможет удовлетворить востребования в лизинге на профессиональном уровне к которому в науке хозяйственного права взрос научный интерес. Разработаны и сформулированы теоретические и практические положения относительно управления лизинговой компанией в форме акционерного общества.

Ключевые слова: лизинговая компания, органы управления, акиионерное общество.

\section{Mentuh N.}

Legal opinion of leasing company management authorities in the form of joint stock company

The article deals with the management of the leasing company as a major leasing participant, without which the normal functioning of the leasing process, which can satisfy the needs for leasing services on a professional basis, and to which scientific interest has grown in business law. The basic theoretical and practical provisions concerning the governing bodies of the leasing company in the form of a joint stock company have been developed and formulated.

It should be noted that despite the development of this problem, a number of issues remain unexplored and require a thorough definition and generalization. Therefore, this article is devoted to solving such problems as the governing bodies of a leasing company in the form of a joint stock company.

Analyzing the current legislation, we can conclude that the vast majority of norms closely link the management of the company with the bodies of the company.

According to the current legislation, the management of a joint-stock company (leasing company) is carried out by its governing bodies, which include: the general meeting as the supreme management body of the company, the supervisory board, which protects the rights of shareholders of the company and regulates the activities of the board, the executive body (board), which manages the current activities of the company, the audit committee.

As a result, it can be noted that some of the problematic issues of the legal status of the governing bodies of a leasing company in the form of a joint-stock company, as the most common organizational and legal form of economic entities, are not fully resolved today due to insufficient regulation at the legislative level.

Keywords: leasing company, bodies of activity, joint-stock company.

Постановка проблеми. Для надання лізингових послуг створюються такі господарські організації, як лізингові компанії, які вважаються основними учасниками лізингової діяльності. В останні роки у вітчизняній науці господарського права зріс науковий інтерес не тільки до дослідження правового становища лізингових компаній, а й до їх органів управління.

Аналіз наукових досліджень та публікацій. У процесі написання статті були використані праці таких українських та зарубіжних науковців як: І. Є. Якубівського, О. В. Трофімової, Д. С. Січка, В. С. Різника, В. А. Горемикіна, О. В. Кабатової, В. Д. Газмана, Ю. Харитонова, В. Вітрянського, А. Асташкіної, І. Решітник та ін.

(๖) Наталія Ментух, 2019 
Ментух $\mathrm{H}$.

Правове становище органів управління лізингової компанії у формі акціонерного товариства

Мета статті. Варто зазначити, що незважаючи на наявність розробок з цієї проблеми, ряд питань все ще є не дослідженими і потребують грунтовного визначення та узагальнення. Відповідно стаття присвячується вирішенню таких проблем, як органи управління лізингової компанії у формі акціонерного товариства.

Виклад основного матеріалу дослідження. Під управлінням господарською діяльністю автори Науково-практичного коментарю ГК України розуміють підзаконну владну діяльність 3 організації господарських зв'язків, що здійснюється органами державної влади, місцевого самоврядування, наділеними господарською компетенцією, а також громадянами, громадськими та іншими організаціями, які є засновниками суб'єктів господарювання чи здійснюють щодо них організаційно-господарські повноваження на підставі відносин власності [1, с. 300].

Окремі дослідники зазначають, що орган юридичної особи - це правова конструкція, що створюється з метою надання можливості сформувати і виразити волю останньої. За правовою природою орган юридичної особи є інституціонально-функціональний їі представник, якому притаманні певні ознаки: законність створення; організаційна сформованість; прийняття рішень (здійснення повноважень) у межах компетенції з додержанням процедури їх оформлення [2, с. 101].

Управління юридичною особою (суб’єктом господарювання), а саме: управління лізинговою компанією (акціонерним товариством), має притаманні тільки їй ознаки, наявність яких обумовлює необхідність спеціального врегулювання відносин з управління цією компанією. Не слід забувати, що оптимальна побудова внутрішньої організаційної структури та адекватної системи органів управління - це запорука успішної діяльності лізингової компанії.

На наш погляд, доцільно більш детально проаналізувати особливості правового статусу органів управління лізингової компанії у формі акціонерного товариства. Аналізуючи чинне законодавство можна дійти висновку, що переважна більшість норм тісно пов'язує управління товариством з органами товариства.

У статуті юридичної особи повинен передбачатися склад та компетенція органів управління та порядок прийняття ними рішень. Згідно з п. 14 ч. 2 ст. 13 Закону України «Про акціонерні товариства»[3] в статуті акціонерного товариства повинен бути зазначений склад органів товариства та їх компетенція, порядок утворення, обрання й відкликання їх членів та прийняття ними рішень, а також порядок зміни складу органів товариства та їх компетенції.

Відповідно до чинного законодавства, управління акціонерним товариством (лізинговою компанією), здійснюють його органи управління, до яких належать: загальні збори як вищий орган управління товариства, наглядова рада, яка здійснює захист прав акціонерів товариства та регулює діяльність правління, виконавчий орган (правління), який здійснює керівництво поточною діяльністю товариства, ревізійна комісія.

Згідно із Законом України «Про акціонерні товариства» загальні збори визнаються вищим органом управління акціонерного товариства та реалізують контрольну компетенцію щодо правління та інших органів товариства.

Загальні збори акціонерів створюють основну правову базу для діяльності інших органів акціонерного товариства, на підставі якої має здійснюватися управління ним спеціально створеним для цього виконавчим органом. Загальні збори є органом для виразу суспільної (єдиної) волі акціонерів (учасників, членів кооперативу) [4, с. 340].

Цей орган визначає напрями діяльності товариства, його стратегію, спрямовує діяльність створених ним підприємств. Рішення цього органу виконує обране ним правління. Хоча рішення загальних зборів акціонерів можуть бути вирішальними для товариства, їх, як слушно зауважив Г. Шершеневич, не варто ототожнювати 3 акціонерним товариством як суб'єктом права [5, с. 411].

Акціонерне товариство зобов'язане щороку скликати загальні збори (річні загальні збори). Рішення про проведення загальних зборів акціонерів приймає наглядова рада товариства. Дії, пов’язані 3 організацією проведення загальних зборів, здійснює правління товариства. Річні загальні збори товариства проводяться не пізніше 30 квітня наступного за звітним року. Усі інші загальні збори, крім річних, вважаються позачерговими.

Слід зазначити, що згідно з ч. 2 ст. 41 Закону України «Про акціонерні товариства» загальні збори акціонерів товариства мають кворум за умови реєстрації для участі у них акціонерів, які сукупно є власниками не менше 50\% голосуючих акцій.

Варто зазначити, що українське законодавство, порівняно з міжнародним, має найвищу планку кворуму. 
Такі підвищені вимоги щодо кворуму, як свідчить практика, можуть викликати певні труднощі при формуванні кворуму, необхідного для проведення загальних зборів акціонерів, відсутність якого призводить до неможливості їх проведення. Тому, на наш погляд, необхідно внести зміни до ч. 2 ст. 41 Закону України «Про акціонерні товариства» шляхом заниження кворуму повторних загальних зборів акціонерів до межі - 30 \% голосуючих акцій. Наприклад, такий кворум передбачено Законом РФ «Про акціонерні товариства» від 26.12. 1995 р. № 208 - Ф3 [6].

Як зазначають окремі дослідники, у Франції для проведення зборів достатньо присутності акціонерів, які володіють 25\% голосуючих акцій. У законодавстві Чехії планка кворуму акціонерних товариств встановлена на рівні простої більшості, тобто 50\% + 1 акція, однак передбачена й норма, коли акціонерне товариство самостійно закріплює в статуті необхідну кількість голосуючих акцій. У Німеччині, Польщі й Болгарії питання кворуму має визначатися в статутних документах акціонерного товариства, в США - та кількість акціонерів, яка присутня на зборах[7, с. 397].

Загальні збори акціонерів є єдиним органом акціонерного товариства, через який кожен акціонер може безпосередньо здійснювати функцію контролю. Проте, як свідчить досвід, компетенція загальних зборів акціонерів щодо контролю за діяльністю товариства не є всеосяжною, а має певні межі. Контрольна компетенція розподіляється між органами корпоративного контролю, формуючи систему корпоративного контролю.

Слід зазначити, що на відміну від Закону України «Про господарські товариства» [8], Закон «Про акціонерні товариства» [3] в ст. 33 значно розширив повноваження загальних зборів. Крім того, передбачена можливість розширювати компетенцію загальних зборів акціонерів у статуті.

На практиці в діяльності акціонерних товариств доцільно дотримуватися принципу «розподілу влади», тобто розмежування компетенції різних органів управління, як це відбувається у окремих зарубіжних країнах. Також важливим є питання визначення повного обсягу компетенції загальних зборів акціонерів, яка б не могла передаватися іншим органам управління. Адже у світовій практиці достатніми гарантіями дотримання інтересів акціонерів $є$ законодавче закріплення основоположних повноважень загальних зборів акціонерів, які насамперед стосуються інтересів самих акціонерів, а саме: порядок внесення змін до статуту, затвердження річних звітів про діяльність товариства; визначення напряму формування прибутку товариства; формування органів управління товариства; питання ліквідації та реорганізації товариства тощо.

Вбачаємо за доцільне визначити в статуті лізингової компанії перелік питань, які становлять виключну компетенцію загальних зборів та питань, які за рішенням загальних зборів акціонерів, можуть бути передані наглядовій раді та правлінню.

Наглядова рада лізингової компанії у формі акціонерного товариства є органом, що здійснює захист прав акціонерів та в межах своєї компетенції контролює та регулює діяльність виконавчого органу.

Відповідно наглядова рада є органом управління акціонерного товариства, уповноваженого представляти інтереси акціонерів у період між проведенням загальних зборів, а також регулювати й контролювати діяльність правління [9, с. 56].

Відповідно до законодавства, в акціонерних товариствах, де кількість акціонерів - власників простих акцій - становить 10 осіб і більше створення наглядової ради є обов'язковим. У товаристві, де налічується 9 і менше акціонерів - власників простих акцій, у разі відсутності наглядової ради ії повноваження здійснюються загальними зборами.

Функціональне призначення наглядової ради як органу управління акціонерного товариства пов'язується з необхідністю здійснення контролю за діяльністю правління. Наглядова рада є органом товариства, що здійснює захист прав акціонерів товариства, і в межах компетенції, визначеної статутом та законом, контролює та регулює діяльність правління.

Сама ідея створення цього органу, а також певні права, обов’язки та функції були запозичені з акціонерного права Німеччини. Як і Німеччині, так і в багатьох зарубіжних країнах наглядові ради на рівні закону наділені широкими повноваженнями щодо здійснення контролю за поточною діяльністю товариства.

Порядок створення, роботи, виплати винагороди та відповідальність членів наглядової ради визначається законом, статутом, положенням про наглядову раду лізингової компанії, а також договором, що укладається з членом наглядової ради.

Без цього органу, як зазначається в літературі, у керівництві радою директорів та генеральним директором немає прозорості, а акціонери не мають механізму контролю за діяльністю компанії[10]. 
Ментух $\mathrm{H}$.

Правове становище органів управління лізингової компанії у формі акціонерного товариства

В Україні наглядова рада є самостійним органом управління товариством, чинне законодавство встановлює і кількісний склад відповідно до статуту акціонерного товариства. Мінімальна кількість членів наглядової ради публічного акціонерного товариства не може бути меншою, ніж 5 осіб. Якщо кількість членів наглядової ради, повноваження яких дійсні, становить менше половини їі кількісного складу, обраного відповідно до вимог закону загальними зборами акціонерного товариства, товариство протягом трьох місяців має скликати позачергові загальні збори для обрання решти членів наглядової ради, а в разі обрання членів наглядової ради шляхом кумулятивного голосування - для обрання всього складу наглядової ради акціонерного товариства (ч. 11, 12 ст.53 Закону «Про акціонерні товариства»).

Компетенція наглядової ради визначається Законом України «Про акціонерні товариства». До виключної компетенції наглядової ради належать вирішення тих питань, які передбачені законом чи статутом, а також тих, які передані для вирішення загальними зборами.

В. С. Щербина зазначає, що функції наглядової ради поділяються на контрольні у сфері управління та контрольні у сфері господарської діяльності товариства. У першій сфері рада затверджує голову правління, за його поданням - членів правління, аналізує дії правління щодо управління товариством. У другій сфері рада розглядає та аналізує звіти правління, ревізійної комісії товариства; аналізує дії правління щодо реалізації інвестиційної, технологічної та цінової політики; додержання товариством номенклатури товару (послуг); є ініціатором позачергових ревізій та аудиторських перевірок господарських і фінансових результатів роботи товариства; погоджує операції товариства щодо розпорядження майном на визначену статутом суму; вносить засновнику і зборам пропозиції з питань діяльності товариства. Рада не має права втручатися в оперативні дії товариства [11, с. 84-85].

Так, наприклад, обов'язками наглядової ради в Польщі $є$ такі: оцінювання звітів та звітів (звіт Правління про діяльність компанії та фінансові звіти за попередній фінансовий рік) щодо їх відповідності книгам, документам та фактам; оцінювання пропозицій правління щодо розподілу прибутку або покриття збитків; подання річного звіту на загальні збори, що представляє результат вищезазначеного оцінювання. Для виконання своїх обов'язків наглядова рада може перевіряти всі документи компанії, запитувати звіти та пояснення з правління та працівників та переглянути активи та зобов'язання компанії [12].

Зазначимо, що найбільш вагомою складовою компетенції щодо функції контролю діяльності правління є право обирати та відкликати голови й членів правління товариства, а також встановлення винагороди та відповідальності членів наглядової ради, затвердження угод, які закріплені в статуті. Вважаємо за доцільне в статуті акціонерного товариства - лізингової компанії - передбачати конкретний вид угод, які потребують затвердження наглядової ради.

Виконавчим органом лізингової компанії, створеної у формі акціонерного товариства, який здійснює управління поточною діяльністю товариства, є правління.

Виконавчий орган вирішує всі питання діяльності товариства, крім тих, які належать до виключної компетенції загальних зборів і наглядової ради товариства. Правління лізингової компанії обираються на загальних зборах і воно підзвітне загальним зборам та наглядовій раді, організовує виконання їх рішень та відповідальне перед ними за результати своєї роботи.

Відповідно склад правління акціонери вибирають на загальних зборах. Правління є колегіальним органом, однак законодавець не встановлює вимог щодо його кількісного складу, як, насамперед у зарубіжному акціонерному праві. Так, за законодавством Німеччини, Франції, Угорщини та деяких інших країн, визначаються вимоги до кількісного складу правління акціонерного товариства, який може залежати від чисельності акціонерів, від розмірів основного капіталу, допущення акцій товариства до котирування на біржі[7, с. 397].

Виконавчий орган може бути колегіальним (правління, дирекція) чи одноособовим (директор, генеральний директор). Щодо особового органу, то в літературі з цього приводу зазначається, що в структурі лізингової компанії, крім генерального директора, можуть передбачатися посади фінансового директора, директора $з$ комерційних та загальних питань [13, с.16]. Ми погоджуємось із цим твердженням, оскільки успішна діяльність лізингової компанії в часто визначається раціональною побудовою їі внутрішньої організаційної структури і формування адекватної системи органів управління. Повноваження правління зазначаються в статуті лізингової компанії.

Функція внутрішньофірмового контролю пов’язується з діяльністю органу, уповноваженого перевіряти відповідність дійсному положенню справ акціонерів відомостей, що представляються загальним зборам про результати фінансово-господарської діяльності акціонерних товариств. Згідно $з$ чинним законодавством цю функцію виконує ревізійна комісія акціонерного товариства - лізингова компанія, яку 
обирають на загальних зборах. Крім того може проводитися і зовнішня перевірка - аудиторська - перевірка фінансово-господарської діяльності правління.

Відповідно до чинного законодавства, в акціонерних товариствах з кількістю акціонерів - власників простих акцій товариства - до 100 осіб запроваджується посада ревізора (обирається ревізійна комісія), а в товариствах з кількістю акціонерів - власників - 100 осіб обов'язково обирається ревізійна комісія.

Ревізійна комісія проводить перевірку фінансово-господарської діяльності товариства за результатами фінансового року, про що готує висновок. Їй надається право скликання позачергових загальних зборів акціонерів у разі виникнення загрози інтересам товариству або виявлення зловживань, вчиненими іiі посадовими особами.

Як зазначається в літературі, об’єктом перевірки є діяльність компанії, у т. ч. ідентифікація та оцінювання ризиків, що випливають з результатів, та напрямок своєї фінансово-господарської діяльності[14].

О. М. Вінник з цього приводу зазначає, що за наявності в акціонерному товаристві наглядової ради вона разом з ревізійною комісією є двома органами, які контролюють діяльність правління. Ці органи мають багато загальних рис - вони обираються і відкликаються загальними зборами акціонерів, підзвітні йому, формуються 3 акціонерів, їх порядок діяльності і кількісний склад затверджуються зборами акціонерів відповідно до статуту товариства, обидва ці органи мають право вимагати скликання позачергових загальних зборів. Проте між ними є суттєва відмінність, виокремлює науковець:

- по-перше, наглядова рада має обмежитися контролем діяльності правління (і одночасно всієї діяльності виконавчого органу, зокрема фінансово-господарської), а ревізійна комісія має контролювати тільки фінансово-господарську. Тобто відмінностями між контролем автор вбачає в тому, що наглядова рада контролює тільки діяльність правління, а ревізійна комісія - діяльність товариства загалом, зокрема його філій, представництв, дочірніх підприємств унітарного типу;

- по-друге, якщо наглядова рада діє постійно, періодично збираючись на свої засідання, то ревізійна комісія здійснює перевірки за певних обставин - наявності відповідного рішення про їх проведення;

- по-третє, ревізійна комісія докладає про результати проведення нею перевірок на загальних зборах акціонерів і наглядовій раді, а наглядова рада звітує тільки перед загальними зборами;

- по-четверте, члени ревізійної комісії мають право брати участь з правом дорадчого голосу в засіданнях правління, а для членів наглядової ради такого права не передбачено [15, с. 158-159].

Ми погоджуємося з цими твердженнями, оскільки вказані відмінності є доволі вагомими. Ревізійна комісія, на відміну від наглядової ради лізингової компанії у формі акціонерного товариства, контролює достовірність та повноту даних фінансової звітності за відповідний період, виявляє факт порушення законодавства під час провадження фінансово-господарської діяльності компанії.

Дискусійним є питання визнання ревізійної комісії самостійним органом внутрішньофірмового контролю. Як зазначають окремі дослідники, в багатьох зарубіжних країнах функції ревізорів виконують незалежні спеціалісти чи професійні організації, що робить найбільш ефективним контроль за діяльністю правління [16, с. 229].

На нашу думку, ревізійна комісія лізингової компанії має право на надання їй такого статусу, оскільки лізингові компанії мають справу з грошовими засобами, а наявність органу, який би спеціалізувався на перевірці достовірності фінансових даних, є вкрай необхідним.

Підтримуємо точку зору О. М. Вінник, яка в науковій праці зазначає, що необхідність ревізійної комісії обумовлена тим, що брати участь в органах управління можуть не тільки акціонери, а й особи, що виконують функції членів правління, керівників структурних підрозділів і головних фахівців на основі трудового договору. Діяльність вказаних посадових осіб та органів, сформованих за їх участі, вимагає перевірки з боку акціонерів з метою захисту інтересів акціонерів [15, с.157].

Покладення функції контролю на ревізійну комісію, сформовану тільки з акціонерів, перш за все, має на меті забезпечення приватних інтересів акціонерів щодо господарського використання викладених ними коштів. Ревізійна комісія відповідно до їі завдань здійснює планові та позапланові перевірки фінансово-господарської діяльності товариства, його філій та представництв, за підсумками яких робить висновки, без чого загальні збори не мають права затверджувати річний баланс товариства.

Як бачимо, необхідність цього органу є безперечною. Відповідаючи на запитання, кому потрібна ревізійна комісія, О. Кравченко зазначає, що ревізійна комісія необхідна всім акціонерам для того, щоб виконувати роботу, яка стосується як матеріальних, так і нематеріальних прав акціонерів. Вона повинна мати реальні можливості не тільки контролювати діяльність виконавчих органів, а й запобігати можливим порушенням прав акціонерів і усувати їх. Крім того, вона необхідна правлінню і наглядовій раді, оскільки 
може не тільки запобігати порушенням, що виникають умисно або помилково, а й допомагати цим органам у пошуку засобів для виходу з деяких критичних фінансових і господарських ситуацій [17].

Висновки. Враховуючи все вищезазначене, зауважимо, що окремі проблемні питання правового становища органів управління лізингової компанії у формі акціонерного товариства як найбільш поширеної організаційно-правової форми суб'єктів господарювання, сьогодні залишаються не повністю вирішеними через недостатнє регулювання на законодавчому рівні.

Так, контроль діяльності виконавчого органу був би неповним без здійснення внутрішньої ревізійної перевірки, поряд з якою може призначатися і зовнішня - аудиторська, яка згідно з чинним законодавства має бути проведена на вимогу акціонера (акціонерів), який є власником більше як 10 \% акцій товариства. Ревізійна комісія - це самостійний орган товариства, на яку покладено обов'язок захисту інтересів акціонерів у сфері господарського використання акціонерного капіталу. 3 метою підвищення якості проведення перевірок, доцільно надати право ревізійній комісії залучати експертів, фахівців (наприклад, з маркетингу, страхування тощо), консультантів на оплатній основі, що стимулювало б роботу самого органу.

Водночас організація роботи ревізійної комісії лізингової компанії (акціонерного товариства) має здійснюватися на підставі закону, а також внутрішніх нормативних актів товариства, що деталізують процедуру формування та діяльність цього органу, його функції, права та обов'язки членів комісії, з урахуванням специфіки діяльності конкретної лізингової компанії (акціонерного товариства). Щодо питання відповідальності членів ревізійної комісії за невиконання, неналежне виконання своїх обов'язків або зловживання своїми правами, то це має регулюватися законом.

\section{Список використаних джерел}

1. Науково-практичний коментар Господарського кодексу України / кол. авт. : Г. Л. Знаменський, В. В. Хахулін, В. С. Щербина та ін.; за заг. ред. В. К. Мамутова. Київ : Юрінком Інтер, 2004. 687 c.

2. Борисова В. Органи управління юридичної особи як їі інституціонально-функціональні представники. Право Украӥни. 2006. № 6. С. 97-102.

3. Про акціонерні товариства: Закон України від 17 вересня 2008 року №514-VI. Відомості Верховної Ради Украӥни. 2008. № 50-51. Ст. 384.

4. Спасибо-Фатєєва I., Кібенко О., Борисова В. Корпоративне управління. / за ред. проф. I. СпасибоФатєєвої. Харків : Право, 2007. 500 с.

5. Шершеневич Г. Ф. Курс торгового права. Москва, 2005. Т. 1.524 с.

6. Об акционерных обществах: Федеральный закон Российской Федерации от 26 декабря 1995 года № 208-Ф3. URL: http://www.consultant.ru/document/cons_doc_LAW_8743 (дата звернення: 15.11.2019).

7. Попадинець Г. Проблемні питання правового статусу органів управління акціонерними товариствами. Вісник Національного університету «Львівська політехніка». Юридичні науки. 2017. № 861. C. 395-400. URL: http://science.lpnu.ua/sites/default/files/journal-paper/2018/jun/13064/395-400.pdf (дата звернення: 15.11.2019).

8. Про господарські товариства: Закон України від 19 вересня 1991 року № 1576-XII. Biдомості Bepховної Ради Украӥни. 1991. № 49. Ст. 682.

9. Величко О. Г., Войтович О. Г., Прилипко С. І. Органи управління акціонерним товариством. Aудитор України. 2009. № 5-6. С. 56-59.

10. Viet Nguyen Supervisory board in joint stock company - how to truly understand? URL: https://www.linkedin. com/pulse/supervisory-board-joint-stock-company-how-truly-viet-nguyen (дата звернення: 17.11.2019).

11. Щербина В. С. Господарське право: Підручник. Київ: Юрінком Інтер, 2003. 480 с.

12. Supervisory Board in Polish Corporate Law. URL: https://www.hg.org/article.asp?id=37566 (дата звернення: 19.11.2019).

13. Лизинг экономические и правовые основы : учеб. пособие для вузов / Карп М. В., Шабалин Е. М., Эриашвили Н. Д., Истомин О. Б.; под ред. Н. М. Коршунова. 2-е изд., перераб. и доп. Москва : ЮНИТИ-ДАНА, 2001. 191 с.

14. REGULATIONS on the Audit Commission of Public Joint-Stock Company Federal Hydro-Generating Company. URL: http://www.eng.rushydro.ru/upload/iblock/f73/REGULATIONS-on-the-Audit-Commission. pdf (дата звернення: 21.11.2019). 
15. Вінник О. М. Публічні і приватні інтереси в господарських товариствах: проблеми правового забезпечення. Київ : Атіка, 2003. 352 с.

16. Кибенко Е. Р. Копоративное право : учеб. пособие. Харков : Эспада, 1999. 480 с.

17. Кравченко Ю. Кому потрібна ревізійна комісія? Українська інвестиційна газета. 1996. 25 червня (19).

\section{References}

1. Naukovo-praktychnyi komentar Hospodarskoho kodeksu Ukrainy [Scientific and Practical Commentary to the Economic Code of Ukraine]. Kol. avt.: H. L. Znamenskyi, V.V. Khakhulin, V. S.Shcherbyna ta in. (2004). Za zah. red. V. K. Mamutova. Kyiv: Yurinkom Inter [in Ukrainian]

2. Borysova, V. (2006). Orhany upravlinnia yurydychnoi osoby yak yii instytutsionalno-funktsionalni predstavnyky [Bodies of management of a legal entity as its institutional and functional representatives]. Pravo Ukrainy - Law of Ukraine, 6, 97-102 [in Ukrainian]

3. Zakon Ukrainy Pro aktsionerni tovarystva: pryiniatyi 17 veresnia 2008 roku № 514-VI. [Law of Ukraine On Joint Stock Companies adopted from September 172008 № 514-VI]. (2008, September 17). Vidomosti verkhovnoi Rady Ukrainy - Information of the Verkhovna Rada of Ukraine, 17, 514 [in Ukrainian].

4. Spasybo-Fatieieva I., Kibenko O., Borysova V.; Za red. prof. Spasybo-Fatieievoi I. (2007). Korporatyvne upravlinnia - Corporative management. Kh.: Pravo [in Ukrainian]

5. Shershenevych H. F. (2005). Kurs torhovoho prava [The course of commercial law] . M. [in Russian]

6. Federalnbii zakon Rossyiskoi Federatsyy Ob aktsyonernblkh obshchestvakh ot 26 dekabria 1995 hoda № 208-FZ. [The course of commercial law]. Retrieved from http://www.consultant.ru/document/cons_doc_ LAW_8743/[in Ukrainian].

7. Popadynets, H. (2017). poblemni pytannya pravovoho statusu orhaniv upravlinnya aktsionernymy tovarystvamy [Problematic issues of the legal status of joint-stock companies management bodies]. Visnyk Natsionalnoho universytetu «Livska politekhnika». Yurydychni nauky - Bulletin of the National University «Lviv Polytechnic». Law, 861. Retreived from http://science.lpnu.ua/sites/default/files/journal-paper/2018/ jun/13064/395-400.pdf [in Ukrainian].

8. Zakon Ukrainy Pro hospodarski tovarystva: pryiniatyi vid 19 veresnia 1991 roku № 1576-XII [Law of Ukraine On Business Societies adopted from September 191991 1576-XII]. (1991, September 19). Vidomosti Verkhovnoi Rady Ukrainy - Information of the Verkhovna Rada of Ukraine, 19, 1576 [in Ukrainian].

9. Velychko, O.H., Voytovych, O.H., Prylypko, S.I. (2009). Orhany upravlinnia aktsionernym tovarystvom [Management bodies of a joint-stock company] Audytor Ukrainy - Auditor of Ukraine, 5-6, 56-59 [in Ukrainian]

10. Viet Nguyen Supervisory board in joint stock company - how to truly understand? Retreived from https:// www.linkedin.com/pulse/supervisory-board-joint-stock-company-how-truly-viet-nguyen [in English].

11. Shcherbyna, V.S. (2003). Hospodarske pravo [Commercial law]. Kyiv: Yurinkom Inter [in Ukrainian].

12. Supervisory Board in Polish Corporate Law. Retreived from https://www.hg.org/article.asp?id=37566 [in English]

13. Karp, M. V., Shabalynm, E. M., Eriash, N. D., Ystomyn O. B.; Pod red. N. M. Korshunova (2001). Lyzynh ekonomycheskye y pravovble osnovbl: Ucheb. posobye dlia vuzov [Leasing Economic and Legal Basics]. Moskva: YuNYTY - DANA [in Russian]

14. REGULATIONS on the Audit Commission of Public Joint-Stock Company Federal Hydro-Generating Company. Retreived from http://www.eng.rushydro.ru/upload/iblock/f73/REGULATIONS-on-the-AuditCommission.pdf [in English].

15. Vinnyk O.M. (2003) Publichni i pryvatni interesy v hospodarskykh tovarystvakh: problemy pravovoho zabezpechennia [Public and Private Interests in Business Societies: Problems with Legal Support] Kyiv: Ataka [in Ukrainian].

16. Kybenko, E.R. (1999). Koporatyvnoe pravo: Ucheb. posobye [Corporate Law: A Study Guide]. Kharkiv: Espada [in Russian].

17. Kravchenko, Yu. (1996). Коли potribna reviziina komisiia? [Who needs an audit committee?].Ukrainska investytsiina hazeta - Ukrainian Investment Newspaper, 25 chervnia (19) [in Ukrainian]. 